\title{
Uji Efektivitas Minyak Atsiri Jeruk Nipis (Citrus Aurantiifolia) Sebagai Larvasida Nyamuk Aedes Aegypti
}

\author{
Kamiel Roesman Bachtiar', Susanti ${ }^{2}$, Srie Rezeki Nur Endah ${ }^{3}$, Lina Rahmawati Rizkuloh ${ }^{4}$ \\ ${ }^{1234}$ Prodi Farmasi, Universitas Perjuangan, Jl. Pembela Tanah Air (PETA) No 177 \\ Tasikmalaya, Indonesia, 46111 \\ Correspondence: Lina Rahmawati Rizkuloh (lina@unper.ac.id) \\ Received: 260721 - Revised: 280721 - Accepted: 100921 - Published: 150921
}

\begin{abstract}
Abstrak.. Berbagai jenis tanaman di Indonesia telah diketahui mengandung senyawa bioaktif yang dapat dimanfaatkan sebagai biopestisida. Salah satumya adalah penggunaan minyak atsiri jeruk nipis yang mengandung limonoida yang dapat berfungsi sebagai larvasida. Tujuan dari penelitian ini adalah mengetahui efektifitas daya bunuh minyak atsiri jeruk nipis (Citrus aurantifolia) terhadap kematian larva nyamuk Aedes aegypti. Objek dalam penelitian ini adalah semua larva Aedes aegypti instar III yang berumur 3-4 hari Sampel total yang digunakan pada penelitian ini sebanyak 360 larva, yang di tentukan dengan teknik Purposive Sampling. Hasil penelitian menunjukkan ada pengaruh minyak atsiri jeruk nipis (Citrus aurantifolia) terhadap kematian larva nyamuk Aedes aegypti. Diperolah konsentrasi minyak atsiri jeruk nipis (Citrus aurantifolia) yang efektif dalam membunuh larva nyamuk Aedes aegypti dalam waktu 24 jam adalah konsentrasi 80 ppm yang merupakan konsentrasi terkecil yang dapat membunuh larva sebanyak 100\%. Hasil estimasi LC $_{50}$ melalui Analisis Probit adalah pada konsentrasi 46 ppm. Sehingga dapat ditarik kesimpulan bahwa konsentrasi efektif minyak atsiri jeruk nipis (Citrus aurantifolia) yang dapat membunuh 50\% (LC50) dalam mematikan larva instar III nyamuk Aedes aegypti adalah konsentrasi 46 ppm dalam waktu 24 jam.
\end{abstract}

Kata kunci: Minyak atsiri, jeruk nipis, larvasida, Aedes aegypti

Citation Format: Bachtiar. K.R., Susanti., Endah. S.R.N., \& Rizkuloh. L.R. (2021). Uji Efektivitas Minyak Atsiri Jeruk Nipis (Citrus Aurantiifolia) Sebagai Larvasida Nyamuk Aedes Aegypti. Prosiding Seminar Nasional Abdimas Ma Chung (SENAM), 2021, 11-20. 


\section{PENDAHULUAN}

Nyamuk Aedes aegypti merupakan vektor utama penular demam kuning (yellow fever) dan juga vektor penular demam berdarah dengue atau demam berdarah (DBD) di Indonesia. Penyakit Demam Berdarah Darah (DBD) merupakan salah satu masalah kesehatan yang ada di Indonesia. Pada tahun 1968-2009 World Health Organization (WHO) mencatat Indonesia sebagai negara dengan kasus DBD tertinggi di Asia Tenggara (Kemenkes, 2010). Pada tahun 2015, tercatat terdapat sebanyak 126.675 penderita DBD di 34 provinsi di Indonesia dan 1.229 orang di antaranya meninggal dunia. Jumlah tersebut lebih tinggi di bandingkan tahun 2014 yakni 100.347 penderita DBD dan 907 penderita yang meninggal dunia. Seseorang yang terkena DBD akan mengalami demam tinggi mendadak tanpa sebab yang jelas dan mengalami trombositopenia (jumlah trombosit menurun dibawah $100000 / \mathrm{mm}^{3}$ ).

Pengendalian nyamuk aedes aegypti dilakukan pada usia jentik (larva) baik secara mekanik, biologi, kimiawi, atau perubahan sifat genetik. Pengendali alami larva adalah ikan, larva nyamuk yang lebih besar (kanibal), larva capung dan Crustaceae. Pengendalian secara kimiawi menggunakan zat-zat kimia yang bersifat ovisida karena bekerjanya lebih efektif dan hasilnya cepat terlihat dibandingkan dengan pengendalian biologis. Namun hal itu dapat menimbulkan dampak negatif diantaranya pencemaran lingkungan, kematian predator, resistensi serangga sasaran bahkan dapat menyebabkan keracunan pada manusia (Kemenkes, 2016).

Berbagai jenis tanaman di Indonesia telah diketahui mengandung senyawa bioaktif yang dapat dimanfaatkan sebagai biopestisida. Biopestisida dapat menggangu siklus hidup nyamuk, menghambat peletakan telur (antiviposisi), menghambat pertumbuhan, reproduksi, menghambat makan. Salah satu alternatif pengendalian vektor adalah dengan penggunaan insektisida alami untuk mengurangi masalah pencemaran lingkungan (Bisset at al, 2011).Fakta yang lebih penting adalah ekstrak tanaman terkadang lebih efektif dibanding insektisida sintetis karena mengandung metabolit sekunder yang memiliki peran besar dalam mengkontrol nyamuk. Pemanfaatan biopestisida dalam pemberantasan vektor diharapkan mampu menurunkan kasus DBD (Kardinan, 2005).

Salah satu tanaman yang bermanfaat sebagai pestisida alami adalah jeruk nipis (Citrus aurantiifolia) yang merupakan salah satu tanaman penghasil minyak atsiri yang sebagian besar mengandung minyak terbang limonene, flavanoid, linalool dll. Zat-zat tersebut juga berfungsi sebagai pengusir nyamuk (Kardinan, 2005). Flavonoid dapat masuk 
melalui kutikula yang melapisi tubuh larva sehingga dapat merusak membran sel larva serta bekerja sebagai inhibitor kuat sistem pernapasan atau sebagai racun pernapasan (Cania \& Setyaningrum, 2013). Limonene dan linalool mempunyai kemampuan untuk menghancurkan membran sel larva yaitu dengan merusak membran sitoplasma yang berperan dalam mengontrol komposisi internal sel dan mengontrol transport aktif sel.

Pada penelitian (Ekawati at all, 2017) Pemanfaatan Kulit Buah Jeruk Nipis (Citrus aurantifolia) Sebagai Larvasida pada larva nyamuk Aedes aegypti dapat diketahui bahwa konsentrasi yang paling efektif dalam membunuh 50\% larva nyamuk Aedes aegypti adalah 3,419\%. Pada penelitian yang dilakukan (Murdani R, 2014) yaitu Efetivitas Daya Bunuh Ekstrak Daun Jeruk Nipis (Citrus aurantifolia) rata-rata kematian larva setelah 24 jam perlakuan, pada konsentrasi terendah $0,40 \%$ sebesar 21 larva (82\%), dan yang tertinggi pada konsentrasi 0,55\% sebesar 25 larva (100\%).Peningkatan rata-rata kematian larva Aedes aegypti terjadi seiring dengan peningkatan konsentrasi ekstrak daun jeruk nipis (Citrus aurantifolia).

\section{METODE PELAKSANAAN}

Metode penelitian yang dilakukan meliputi Rancangan Penelitian, prosedur penelitain dan pengolahan data hasil penelitian.

\section{Rancangan Penelitian}

a. Minyak Atsiri Jeruk Nipis (Citrus aurantiifolia) dengan konsentrasi 30-80 ppm, kontrol positif yang berisi Abate $0,001 \%$ dan kontrol negatif yang berisi air sumur dimasukan kedalam wadah sesuai dengan label larutan uji.

b. Larva nyamuk sebanyak 20 ekor dimasukkan ke dalam masing-masing larutan uji dengan menggunakan pipet.

c. Jumlah larva mati dihitung setelah perlakuan sampai 24 jam setelah perlakuan.

d. Larva dianggap mati bila tidak ada tanda-tanda kehidupan, misalnya di sentuh dengan lidi tidak ada rangsangan atau tidak bergerak lagi.

e. Pengulangan pengujian dilakukan sebanyak tiga kali. Pengulangan pengujian ini didasarkan dari hasil perhitungan dengan rumus Federer (Sudigdo dan Ismael, 2003), yaitu:

$$
(\mathrm{t}-1)(\mathrm{n}-1) \geq 15
$$


Keterangan:

$\mathrm{n}$ : Banyak perlakuan yang dicoba

$\mathrm{t}$ : Banyaknya ulangan atau kelompok

\section{Prosedur Penelitian}

\section{Penetasan Telur Nyamuk Aedes aegypti}

Kertas saring yang berisi telur Aedes aegypti ditempatkan di wadah berisi air. Lalu telur nyamuk di tetaskan selama 4-5 hari di dalam wadah yang berisi air sumur dan diberi pakan hati ayam yang telah direbus.

\section{Persiapan Larva Instar III Nyamuk Aedes aegypti}

Telur nyamuk yang telah di tetaskan menjadi larva usia 4-5 hari tumbuh menjadi larva instar III, maka dilakukan konfirmasi dengan cara mengamati morfologi larva di mikroskop dengan larva keadaan mati. Selanjutnya larva yang telah mencapai instar III dipindahkan ke dalam wadah yang berisi larutan uji.

\section{Pembuatan Larutan Uji}

Tween80 dengan minyak dicampurkan sampai homogen lalu dihitung jumlah air yang dibutuhkan dalam membuat 100ml larutan. Dipipet masing-masing minyak, air dan tween80 dengan sejumlah yang dibutuhkan. Campurkan minyak dengan tween80 lalu diaduk dengan kuat dan konstan, kemudian ditambahkan air sumur yang telah dipanaskan pada suhu $40-60{ }^{\circ} \mathrm{C}$ sedikit demi sedikit sambil diaduk sampai homogen.

\section{Penentuan Konsentrasi Larutan Uji}

Pada tahap ini, dilakukan pengujian Minyak Atsiri Jeruk Nipis (Citrus aurantiifolia) dengan konsentrasi 30-80 ppm dengan rentang 10 ppm untuk mengetahui jumlah larva yang mati pada rentang konsentrasi tersebut. Kecilnya konsentrasi larutan uji maka dibuat larutan stok yaitu konsentrasi $0,1 \%$ dari larutan induk minyak atsiri jeruk nipis (Citrus aurantifolia) dengan konsentrasi 100\%. Konsentrasi larutan uji dapat dilihat pada Table 1.

Tabel 1. Konsentrasi Larutan Uji

\begin{tabular}{cccc}
\hline \multirow{2}{*}{ No. } & \multirow{2}{*}{ Larutan Uji $(\mathrm{ppm})$} & \multicolumn{2}{c}{ Jumlah larutan } \\
\cline { 3 - 4 } & 30 & 3 & Air $(\mathrm{mL})$ \\
\hline 1 & 40 & 4 & 97 \\
2 & 50 & 5 & 96 \\
3 & 60 & 6 & 95 \\
4 & 70 & 7 & 94 \\
5 & 80 & 8 & 93 \\
6 & & & 92 \\
\hline
\end{tabular}




\section{Pengolahan Data}

Pada penelitian yang diukur dengan presentase kematian larva setelah diberi perlakuan pada selama 24 jam. Pengukuran presentase dilakukan dengan menghitung jumlah larva yang mati sebanyak 20 larva yang diuji kemudian dilakukan Analisis Probit menggunakan program IBM SPSS Statistic 25.0 untuk mengetahui daya bunuh Minyak Atsiri Jeruk Nipis (Citrus aurantiifolia) dengan konsentrasi 30-80 ppm terhadap larva Aedes aegypti yang dinyatakan dengan LC (Lethal Concentration).

\section{HASIL DAN PEMBAHASAN}

Minyak atsiri jeruk nipis adalah minyak mudah menguap yang dihasilkan akar, daun, buah, batang jeruk nipis. Di dalam minyak atsiri jeruk nipis mengandung zat utama yaitu limonene yang mempunyai aroma yang khas serta geraniol dan linaool (Murdani R, 2014). Minyak jeruk nipis (Citrus aurantifolia) yang digunakan pada penelitian adalah minyak atisiri produk jadi dengan merk " $\mathrm{X}$ " yang mengandung $100 \%$ minyak jeruk nipis yang diperoleh dengan cara penyulingan. Penggunaan minyak atsiri jeruk nipis ini karena pada jeruk nipis mengandung senyawa-senyawa yang dapat membunuh larva diantaranya limonene yang merupakan senyawa paling banyak yang terkandung pada minyak atsiri jeruk nipis tersebut.

Minyak atsiri jeruk nipis (Citrus aurantifolia) mempunyai sifat yang tidak larut di dalam air maka di lakukan penambahan zat pelarut yaitu larutan Tween80 yang dapat meningkatkan kelarutan minyak terhadap air. Minyak jeruk nipis dicampurkan dengan larutan Tween80 dengan perbandingan 1:5 yang didasarkan dari percobaan perbandingan sampai larutan berwarna jernih stabil. Menurut (Widawati et al, 2013) tween80 adalah ester asam lemak berwarna kuning, seperti minyak, berbau khas lemah dan mempunyai rasa pahit. Tween80 bersifat non-ionik yang berfungsi sebagai surfaktan. Surfaktan merupakan suatu molekul yang memiliki gugus hidrofilik dan gugus lioofilik sehingga dapat mendispersikan campuran yang terdiri dari air dan minyak. Larutan Tween 80 tidak memberikan angka kematian pada larva sehingga tidak ada pengaruh terhadap kematian larva.

Subjek penelitian berupa larva Aedes aegypti instar III yang telah dikembangbiakan dari telur nyamuk Aedes aegypti yang diperoleh dari Loka Litbang Pangandaran, ditetaskan dalam waktu 4-5 hari di laboratorium Universitas Perjuangan. Penggunaan larva nyamuk Aedes aegypti instar III karena larva tersebut mempunyai sistem pertahanan lebih kuat, ukuran tubuh yang lebih besar sehingga mudah untuk diidentifikasi dibandingkan dengan 
instar I dan II, selain itu larva instar III merupakan sampel penelitian yang menjadi standard WHO (WHO, 2005). Adapun perbedaan antara larva instar III secara mikroskopis yaitu adanya duri pada dada mulai jelas dan shipon berwarna coklat kehitaman

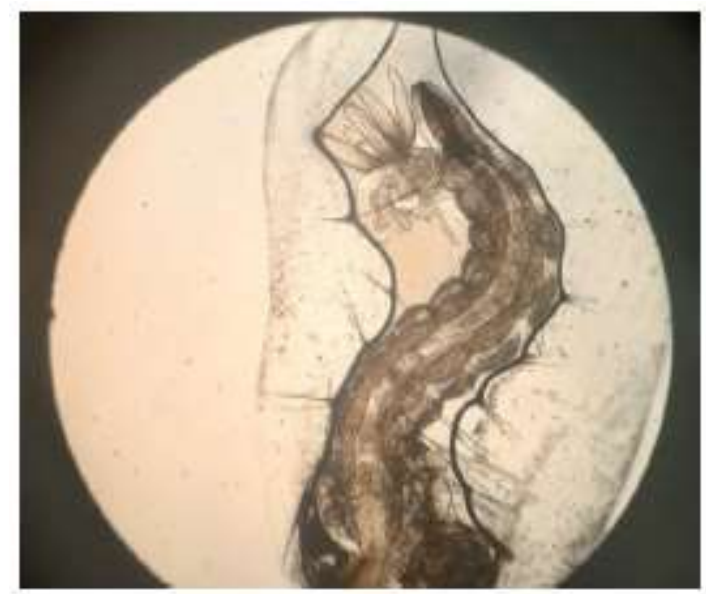

Gambar 1. Larva instar III Nyamuk Aedes aegypti secara mikroskopis

Pada penelitian ini, larutan uji dibuat sebanyak $100 \mathrm{ml}$ dan ditempatkan pada wadah plastik yang kering dan bersih. Larutan uji diambil dari larutan stok yang dibuat dalam konsentrai $0,1 \%$, dibuatnya larutan stok $0,1 \%$ dibuat dari minyak atsiri jeruk nipis berkonsentrasi $100 \%$. Larva Aedes aegypti yang digunakan pada masing-masing larutan uji adalah 20 ekor larva. Larva Aedes aegypti dipindahkan kedalam wadah dengan menggunakan pipet tetes. Wadah ditutup dengan kasa, kemudian ditempatkan di ruangan yang sama. Pengulangan dilakukan sebanyak tiga kali berdarsarkan perhitungan menggunakan rumus dan diamati selama 24 jam setelah perlakuan. Pengamatan dilakukan dengan cara menghitung jumlah larva yang mati pada setiap larutan uji.

Pengamatan larva yang mati ditandai dengan tidak adanya pergerakan pada saat disentuh lidi atau dirangsang dengan pergerakan air. Selain itu, larva berwarna putih pucat atau coklat pucat dengan ukuran larva yang lebih besar, hal tersebut terjadi karena proses osmosis yaitu pergerakan molekul-molekul pelarut dari larutan encer kelarutan yang lebih pekat dimana larutan uji yang bersifat lebih encer masuk ke dalam tubuh larva melalui membran semipermeabel, akibat pergerakan tersebut volume sistem yang berkonsentrasi lebih pekat di dalam tubuh larva akan membengkak dan pigmen tubuh larva larut sehingga tubuh larva yang mati berukuran besar dan berwarna pucat (Moslim et al, 2007). 


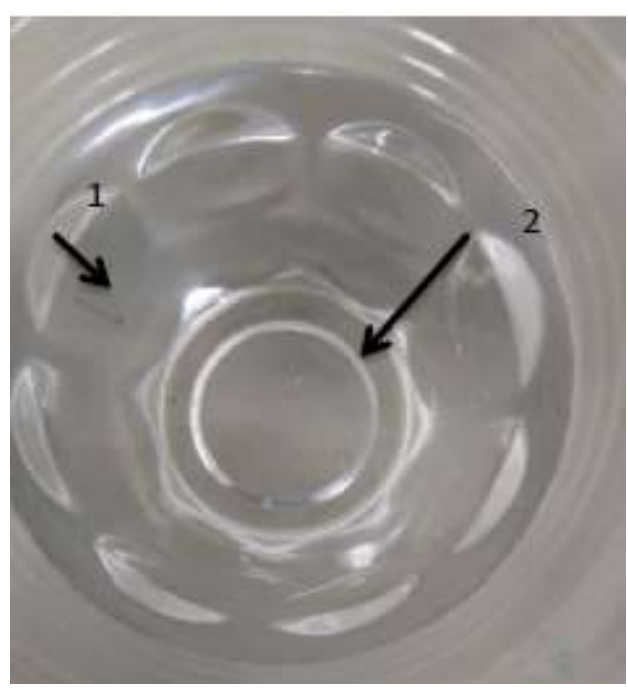

Gambar 2. Larva instar III Nyamuk Aedes aegypti dengan ciri fisik

(1)Masih hidup (2)Sudah mati

Pada Gambar 2 dapat di bedakan ciri fisik antara larva yang masih hidup (1) dan yang telah mati (2). Pada larva nyamuk Aedes aegypti instar III yang masih hidup (1) terlihat mempunyai ciri bergerak pada saat disentuh dengan lidi, adapun yang bergerak aktif. Larva terlihat berwarna hitam kecoklatan dan mengapung sesekali untuk mengambil oksigen. Sedangkan pada larva yang sudah mati (2) terlihat berwarna hitam pucat, coklat pucat ataupun putih pucat dengan ukuran larva yang lebih besar dari pada yang hidup, tidak ada pergerakan pada saat dirangsang dengan pergerakan air ataupun disentuh dengan lidi.

Penentuan jumlah kematian larva nyamuk Aedes aegypti instar III terhadap larutan uji minyak atsiri jeruk nipis (Citrus aurantifolia) dalam waktu 24 jam dapat dilihat pada Tabel 2.

Tabel 2. Hasil Pengujian Konsentrasi Larutan Uji

\begin{tabular}{cccccccc}
\hline \multirow{2}{*}{ No. } & \multirow{2}{*}{ Kelompok Uji } & \multicolumn{7}{c}{ Jumlah Kematian Larva } & Jumlah & Rerata & Presentase \\
\cline { 3 - 8 } & & 1 & 2 & 3 & & & \\
\hline 1 & Kontrol (-) Air sumur & 0 & 0 & 0 & 0 & 0 & $0 \%$ \\
2 & Kontrol (+) (Abate) & 20 & 20 & 20 & 60 & 20 & $100 \%$ \\
3 & Standar (Tween80) & 0 & 0 & 0 & 0 & 0 & $0 \%$ \\
4 & $30 \mathrm{ppm}$ & 3 & 1 & 2 & 6 & 2 & $10 \%$ \\
5 & $40 \mathrm{ppm}$ & 7 & 8 & 8 & 23 & 7,66 & $38 \%$ \\
6 & $50 \mathrm{ppm}$ & 13 & 14 & 12 & 39 & 13 & $65 \%$ \\
7 & $60 \mathrm{ppm}$ & 16 & 14 & 16 & 46 & 15,33 & $76 \%$ \\
8 & $70 \mathrm{ppm}$ & 20 & 19 & 20 & 59 & 19,66 & $98 \%$ \\
9 & $80 \mathrm{ppm}$ & 20 & 20 & 20 & 60 & 20 & $100 \%$ \\
\hline
\end{tabular}


Berdasarkan Tabel 2 menunjukan hasil data penelitian dengan hasil yang bervariasi. Data menunjukan angka kematian tertinggi 100\% adalah konsentrasi 80 ppm dan yang terendah $10 \%$ pada konsentrasi 30 ppm.

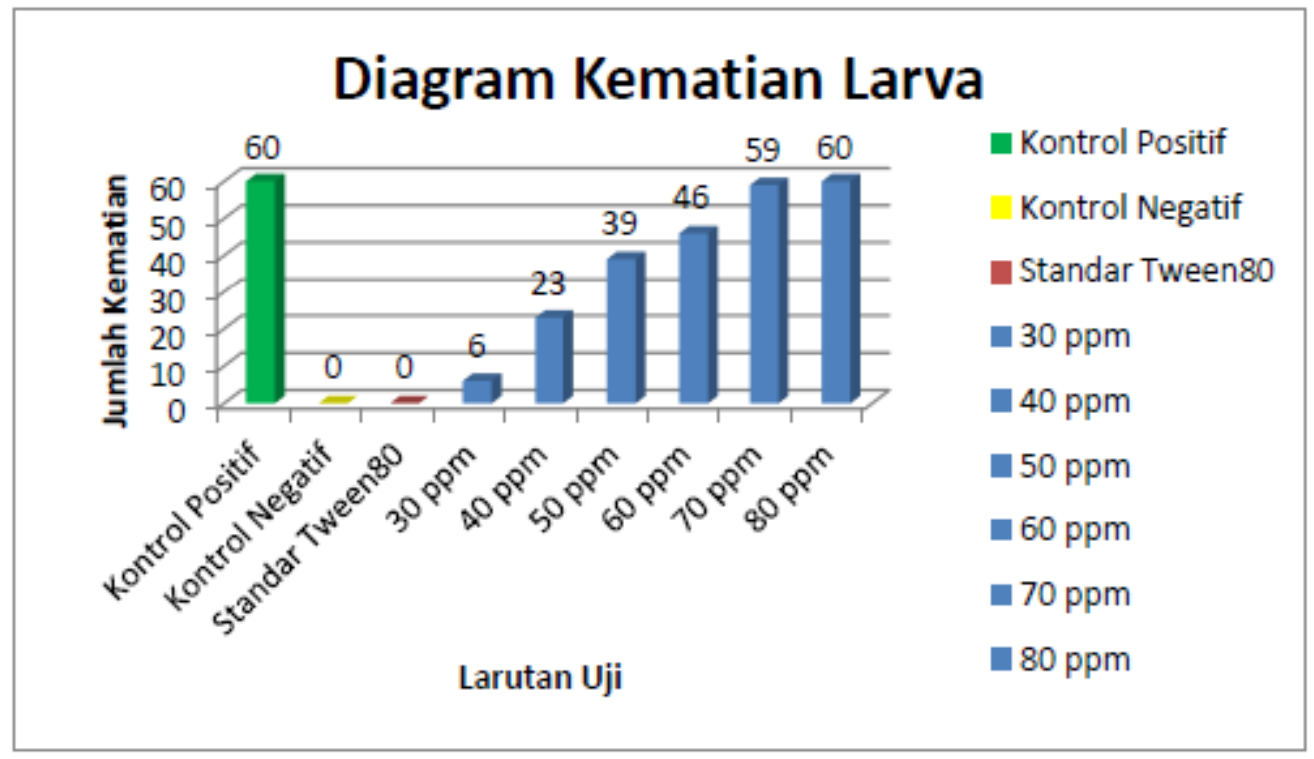

Gambar 3. Diagram Jumlah Kematian larva

Setelah didapatkan data hasil penelitian, selanjutnya data penelitian diuji dengan Analisis Probit dengan tingkat kepercayaan 95\% untuk mengetahui nilai LC50 menggunkan IBM SPSS Statistic 25.0. Analisis statistik yang digunakan adalah menggunakan Analisis Probit untuk mengetahui efektifitas minyak atsiri jeruk nipis (Citrus aurantifolia) pada berbagai konsentrasi dalam membunuh larva Aedes aegypti untuk mendapatkan LC $_{50}$. Hasil estimasi LC $_{50}$ melalui Analisis Probit adalah pada konsentrasi 46 ppm. LC 50 ditentukan berdasarkan dari WHO (2005) dalam Guildelines for Laboratory and Field Testing of Mosquito Larvasides.

Dari data yang diperoleh dapat membuktikan bahwa pada konsentrasi minyak atsiri jeruk nipis yang berbeda mempunyai pengaruh pada kematian larva yang berbeda juga, maka semakin tinggi konsentasi semakin tinggi angka kematian larva sampai tingkat kematian tertentu.

Pada penelitian sebelumnya, yaitu (ER Ekawati et all, 2017) membuktikan bahwa ekstrak kulit jeruk nipis dapat mematikan larva Aedes aegypti pada nilai LC $_{50}$ terletak pada konsentrasi 3,419\%. Sedangkan menurut (Adrianto et all, 2014) bahwa biolarvasida ekstrak metanol jeruk purut (Citrus hystrix) dapat membunuh larva dengan nilai $\mathrm{LC}_{95}$ terletak pada konsentrasi 3.176 ppm atau 0,31\%. Pada penelitian Murdani R (2014) 
menggunakan ekstrak daun jeruk nipis memiliki rata-rata kematian terendah terdapat pada konsentrasi $0,40 \%$ yaiu 21 larva (82\%) dan terbanyak pada konsentrasi $0,55 \%$ dengan kematian larva senayak 25 ekor (100\%). Jika dibandingkan dengan dengan penelitian ini, minyak atsiri jeruk nipis (Citrus aurantifolia) merk " $\mathrm{X}$ " lebih efektif dibandingkan dengan ketiga penelitian sebelumnya, karena minyak jeruk nipis dapat membunuh larva Aedes aegypti dengan nilai $\mathrm{LC}_{50}$ terletak pada konsentrasi 46 ppm, $\mathrm{LC}_{90}$ terletak pada konsentrasi 64 ppm dan LC $_{99}$ pada konsentrasi 83 ppm. Hal ini dikarenakan bahan yang diujikan adalah minyak atsiri hasil dari penyulingan atau hasil destilasi dari bagian buah dan daun jeruk nipis sehingga memiliki kandungan zat kimia limonoid yang lebih murni.

Berdasarkan hasil penelitian ini, penulis menyimpulkan bahwa minyak jeruk nipis (Citrus aurantifolia) merk "X" berpengaruh terhadap kematian larva Aedes aegypti. Kandungan limonoid sebagai zat utama di dalam minyak jeruk nipis merk " $\mathrm{X}$ " lebih berperan sebagai larvasida terhadap larva instar III nyamuk Aedes aegypti. Menurut (Murdani R, 2014) limonoid yang bekerja sebagai racun perut, masuk ke organ pencernaan tubuh larva nyamuk Aedes aegypti dan diserap oleh dinding usus kemudian beredar bersama darah yang akan mengganggu metabolisme tubuh nyamuk sehingga akan kekurangan energi untuk aktivitas hidupnya, sehingga mengakibatkan larva nyamuk kejang dan akhirnya mati. Dengan demikian, berdasarkan cara masuknya minyak atsiri bersifat sebagai racun perut karena insektisida dapat masuk kedalam tubuh serangga.

Berdasarkan penelitian yang telah dilakukan dapat disimpulkan bahwa terdapat pengaruh minyak atsiri jeruk nipis (Citrus aurantifolia) terhadap kematian larva instar III nyamuk Aedes aegypti dengan nilai $\mathrm{LC}_{50}$ pada konsentrasi 46 ppm dalam waktu 24 jam.

\section{UCAPAN TERIMA KASIH}

Penulis mengucapkan terimakasih kepada Univeristas Perjuangan Tasikmalaya yang telah memberikan dukungan finansial melalui Hibah Kompetitif Internal Universitas Perjuangan Tasikmalaya Tahun 2020/2021.

\section{DAFTAR PUSTAKA}

Bisset, J. A., Rodríguez, M. M., Ricardo, Y., Ranson, H., Perez, O., Moya, M., \& Vazquez, A. (2011). Temephos resistance and esterase activity in the mosquito Aedes aegypti in Havana, Cuba increased dramatically between 2006 and 2008. Medical and Veterinary Entomology, 25(3), 233-239.

Cania, E., \& Setyanimgrum, E. (2013). Uji efektivitas larvasida ekstrak daun legundi (Vitex trifolia) terhadap larva Aedes aegypti. Jurnal Majority, 2(4). 
Departemen Kesehatan, Demam Berdarah Dengue di Indonesia tahun 1968-2009, Jendela Epidemiologi, Jakarta, 2010.

Departemen Kesehatan, Laporan Kasus Demam Berdarah Dengue, Depkes RI, Jakarta, 2016.

Departemen Kesehatan, Pencegahan dan Pemberantasan Demam Berdarah, Depkes RI, Jakarta, 2005.

Depertemen Kesehatan, Kebijakan Obat Tradisional Nasional, Depkes RI, 2007.

Ekawati, E. R., Santoso, S. D., \& Purwanti, Y. R. (2017). Pemanfaatan kulit buah jeruk nipis (Citrus aurantifolia) sebagai larvasida Aedes aegypti instar III. Jurnal Biota, 3(1), 1-5.

Kardinan, A. (2003). Tanaman pengusir dan pembasmi nyamuk. Jakarta: Agro Media Pustaka, 2-5.

Mardihusodo, S.J, Mardiyah, Baidwoli, C.A. (2014). Laporan Penelitian Kemampuan Menetas Telur Aedes aegypti (Stegomya) aegypti L, Proyek LPPT, Universitas Gadjah Mada, Yogyakarta.

Moslim, R. A. M. L. E., Kamarudin, N., Na, A. B., Ali, S. R. A., \& Wahid, M. B. (2007). Application of powder formulation of Metarhizium anisopliae to control Oryctes rhinoceros in rotting oil palm residues under leguminous cover crops. Journal of Oil Palm Research, 19, 319..

Murdani, R. (2014). Keefektivan Daya Bunuh Ekstrak Daun Jeruk Nipis (Citrus aurantifolia) Terhadap Kematian Larva Nyamuk Aedes aegypti Instar III (Doctoral dissertation, Universitas Muhammadiyah Surakarta).

Sudarmaja, I. M., \& Mardihusodo, S. J. (2009). Pemilihan tempat bertelur nyamuk Aedes aegypti pada air limbah rumah tangga di Laboratorium. Jurnal Veteriner, 10(4), 205207.

Wijaya LA, Daya Bunuh Ekstrak Biji Kecubung (Datura metel) Terhadap Larva Aedes aegypti, Skripsi, Universitas Sebelas Maret Surakarta, 2009.

World Health Organization (WHO), Comprehensive Guidelines for Prevention and Control of Dengue and Dengue Haemorrhagic Fever,WHO, 2011.

World Health Organization (WHO), Guildelines for Laboratory and Field Testing of Mosquito Larvasides, WHO, 2005.

(C) 2021 by authors. Content on this article is licensed under a Creative Commons Attribution 4.0 International license. (http://creativecommons.org/licenses/by/4.0/). 